\title{
Stimulating Toodler's Intellegence by using Music and Art Activities
}

\author{
Donna Angelina Sugianto ${ }^{1}$ \\ ${ }^{1}$ Faculty of Technology and Design, Universitas Pembangunan Jaya, Tangerang, Indonesia \\ 1donna.angelina@upj.ac.id
}

\begin{abstract}
The growth of early childhood is very important in determining their future development. The golden age phase of the child's growth is at the age of $0-5$ years. At this golden age, parents who become the closest 'friends' of children have a very important role. Since they are still in the inside of their mother's womb, a child already introduced to music. The first music they heard was their mother's heartbeat, which is a rhythm with a constant tempo that follows the emotions that created by their mother's body. Music as a form of creative activity that can help to develop children's intelligence and emotional levels can also be collaborated into a craft art activity that can be created in children's daily activities. In this phase, it is better for children to get positive information from their immediate environment, for example activities related to children's creativity. Creative things can be done in the form of artistic activities such as music (singing, playing musical instruments) and art \& craft (drawing, coloring, making something). From the environment and daily life of these children, they can explore many things by using objects in their surroundings. Through this method we will be able to produce more creative and critical children. Improving the intelligence of early childhood should not be difficult to do because by nature all facilities are available in the environment where the child is growing.
\end{abstract}

Keywords: music, rhythm, DIY, art and craft, instrument, children, activities, exploration

\section{INTRODUCTION}

Medical experts say that the child's development process has a role of as much as $70 \%$ $80 \%$, which is around the age of 3 years [1]. At this age children's accept and absorb a lot of things that happen during their growth and development. It doesn't mean that the age after golden age (0-5 years) is not important, it's just that what they receive in this phase is a series of firsts, much more recorded and can be the basis or foundation in their future development.

In a study conducted by neurologists, the addition of new neuron cells will continue to occur and develop rapidly until the age of children around age of 4-5 [2]. The development of the baby's brain can reach up to hundreds of billions of neurons that are ready to make connections between cells during their first years. In this phase of the cell connection process is a good time where the external parties, namely parents or caregivers are required to respond with external stimuli. As for developments that must be considered in the form of physical development, fine and gross motor skills, verbal skills and social skills development. This brain development occurs in the whole hemisphere of the brain, [2] where each stores different abilities of children 
in both the right and left hemispheres. The left-brain is related to the right hand, foot and body. Also controls activities that are regular, detailed, sequential, constant and systematic. For example counting, reading and writing. And the right brain is associated with the hands, feet and left limbs. It is also control a lot of activities that are broad and imaginative, such as something related to creativity, music, intuition, emotions, free ideas, abstract and simultaneous.

Music and art activities are one form of activity that can be used as a response to the needs of the development of the right brain. As Albert Einstein said, "Imagination is more important than knowledge." Through imagination, children can see the world largely. Imagination is the door to all possibilities. It will stimulate children to think creatively, both creatively in creativity and even creatively in solving a problem. Imagination and creativity are one of how children see the world. Creative is a process where we could explore something (material) and to find or create something (object). From the comparison between children who are given arts activities either music or art \& craft with children who are not given, it looks very different from the way they socialize and think. Children, who are given these methods can more easily blend in with their social life and environment, are more focused and have better motoric sense development. While children who are not given this method are more difficult to establish their social life, they usually do not have much vocabulary, and it is more difficult for them to be able to focus on one thing.

This research focuses on children's responses to music and art activities; and those who are close in their daily lives [3], namely parents, teachers or their companions as facilitators as well as observers. Through this writing is expected to be able to describe how the development of children's intelligence at an early age can be trained through musical activities and creative activities, in the form of activities to make a work of objects that can produce sounds, which will become a tool for learning and playing for children.

\section{METHOD}

This study uses the [4] Regio Emillia Approach (REA) methodology approach where learning is also seen as a journey and education as an effort to build relationships with people and create relationships between ideas and the environment [5]. Project activities that children can do in the form of ideas that can emerge from the children themselves, ideas that are provoked by the teacher, the teacher can introduce what is interesting to discuss, develop ideas and all project activities must be in accordance with reality. An approach that has learning objectives to communicate the power of children's ideas and rights, potentials and resources that are often overlooked; to increase teacher professionalism, also supports a high awareness of the values of cooperation and the meaningful relationship between children and their families. Making the main topic of the values of research, observation, interpretation and documentation of knowledge that is built from the child's thought process.

The first observation to be made of the subject in this case is the children themselves. Observations made were the children's behavior in music, their habits, gestures of children, the way they communicate, interact when alone or in groups, to the daily psychological conditions. Then the following observations made on the object are materials that can produce simple sounds, producing a certain rhythm. After that, it combines children's imagination about their interpretation of a certain sound into tangible objects. Music is a vital part of children's lives, when they can make music themselves it is immensely satisfying for them. 


\section{RESULT AND DISCUSSION}

Children always have a high curiosity. What they see around them can be an inspiration that is outside of our habits in understanding an object. Their imagination is very broad and unlimited. Like the research that has been done by NASA about Creativity Scores at Genius Level. The results were astounding. The proportion of people who scored at the 'Genius Level', were among 5 years olds are $98 \% ; 10$ year olds are $30 \%$; 15 year olds are $12 \%$; and same test given to 280,000 adults at average age of 31 is $2 \%$ only [6].

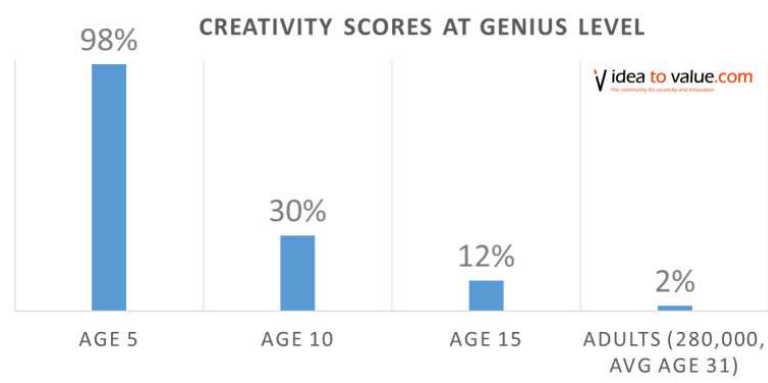

Fig. 1. Creativity Scores At Genius Level Research Chart by NASA (Source: ideatovalue.com)

The environment is one of the factors that can affect children's creativity. What they feel, see, taste, smell and hear through their five senses from the environment accelerates the connectivity that exists between the nerve nodes. Providing opportunities for creativity is as easy as providing paper for drawing, spoons for tapping on a bucket and forming a rhythm. When children say, "Look, I made this picture!" As a facilitator it is best to respond with "Can you tell me about your drawing?" An open response like this gives the child the opportunity to tell his imagination through a picture, where they try to communicate something using their hands through an image on paper.

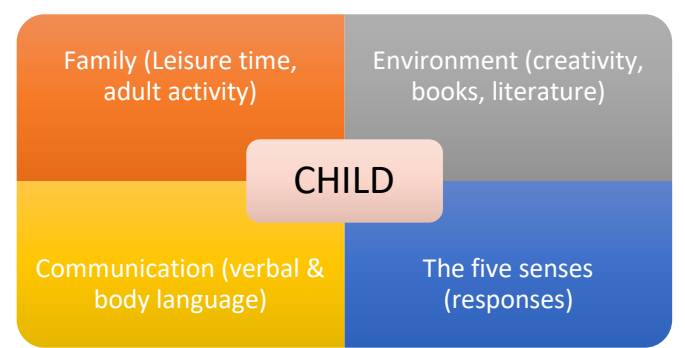

Fig. 2. Factors that influence children's creativity

The elements above (Fig.2) are factors that can influence the development of creativity in children. From these elements, mentoring children outside the family environment, in this case teachers are advised to emphasize children with processes rather than products, allow time for children to explore all possibilities, provide a classroom environment that allows children to explore and play, use creative problem solving in all parts of the curriculum (using naturally occurring in everyday life), adapt to children's ideas rather than trying to structure the children's ideas that fit the adult's. Creative should be something fun and enjoyed. 


\subsection{Music Activity}

The first communication that occurs since a child is born is through sound, namely crying and laughter. If something is uncomfortable the baby usually responds to his body by crying and giving these signals to those around them [7]. From this sound the emotional bond between mother and child is formed. Creating musical activities at an early age can be done through simple things like creating a game using our own body parts that can produce sounds. For example the game of clapping, stomping, snapping fingers, and so on to form a rhythm [8]. Sometimes other musical activities can also be done when the mother wants to ask her child to eat for example, by singing a sentence that contains an persuasion for the children to eat. In this way children who are reluctant to eat, usually become easier to persuade and they are happy to eat. As written in the book "Psychology of Music (The Psychology of Everything)" (2018) written by Susan Hallam, she said "the capacity to make music is present in all humans, and that musicality is as universal as linguistic ability" [9].

Based on the REA methodological approach that all children's activities are centered on the family as the main facilitator. Rhytmical and melodic music activities should be done at any time in the family environment at home or driving while humming, body rhythm games, echo games, rhymes games, etc. Simultaneously, [10] this activity builds vocabulary, improves cognitive, memory and also khinestetic children by using all members of the body.

\subsection{Rhythm Music}

Playing music can be done with a variety of instruments. The instruments can be struck, plucked, banged or shaken to produce many different types of sound. As mentioned above, that the regular rhythm heard by babies from the womb is the sound of the heartbeat of their mother. Rhythm in music is the placement of sounds in time. In its most general sense, rhythm (Greek rhythmos, derived from rhein, "to flow") is an ordered alternation of contrasting elements [11]. The notion of rhythm also occurs in other arts, for example poetry, painting, sculpture and architecture; as well as in nature, for example biological rhythms. These musically inclined learners think in sounds, rhythms and patterns. They will be able to quickly respond to a sound / music either by appreciating or criticizing what they hear. Most learners will be more sensitive to the sounds they hear from their environment, for example sensitive to hearing the sound of water droplets, crickets, buzzing, etc. The results obtained with musical rhythmic understand regularity by keeping body in a beat, body awareness through movements [12], exploring sound, recognizing music patterns and structures, composing music, having a rhythmical feeling, playing musical instruments and being able to remember melodies.

Rhythmic instruments usually result from bodily movements by hitting or shaking, for example tambourines, bells, cymbals, etc. For the golden age, usually this rhythmic music approach is often used because it is adapted to motor development. When playing these musical instruments, children are stimulated to move their limbs according to rhythm such as jumping, beating, singing and dancing. These activities also promote understanding of concept such as up and down, over and under, high and low, soft and loud, short and long, in and out, and stop and go. 


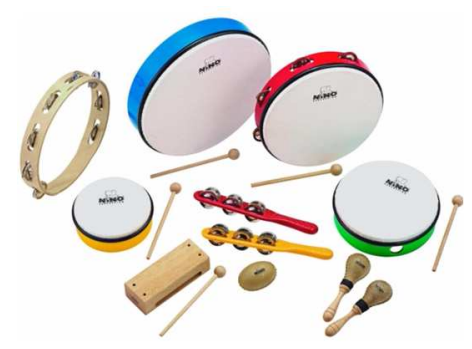

Fig. 3. Music rhythm instruments (Source: musicarts.com)

\subsection{Discover the Music Tools and Art Activity for Children's Development}

Musical instruments can be produced by using a variety of materials available in the surrounding environment. This is where children are introduced to explore, create, interpret a sound and discover new objects that are the result of their interpretation of a sound into an object that is around it, or with the easiest initial way is how to interpret the animal's voice using their own voice. The very first, we could ask our children to imagine some voices; for examples of how they interprets the sound of lightning, the sound of rain, wind etc. We have to make sure that around us there are available objects that support the material we submit to the child. Or can it also be reversed, such; giving the child an empty gallon of mineral water and ask them what sounds can be created by using it? With this kind of stimulation, children will imagine using their five senses [13].

Music created from founded objects is not only can create rhythm, but some of them also can form certain tones and melodies. For example PVC pipes of the same diameter, if cut to different lengths, will produce sounds with different tunes. Art activities by making musical instruments from founded objects give children experience to explore [14]. Rhytmic instruments can also be made from plastic or real eggs filled with rice and then tied to a spoon and become a maracas. Lots of 'do it yourself' (DIY) art activities that can be done at home using objects from household appliances (fig.4).

From the research conducted it was found that children's cognitive development such as their memory becomes better, their creativity is getting higher and their socialization life is also increasing. For example when a child is asked to create a drum sound, through their memory of the drum sound, the child will imagine how to create a drum sound from the objects around him. What they did was try to hit some objects that were found from the kitchen using chopsticks. Through their memory of the sound of drums, the child succeeds in [15] interpreting them into objects for example; Buckets as floor toms and stainless containers as cymbals. Not only that, the child is also able to arrange the drum structure according to his version. 


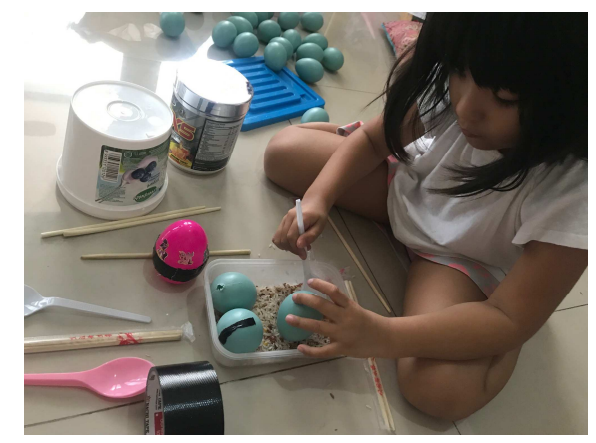

Fig. 4. Creating rhythmic musical instrument with plastic egg, 2019

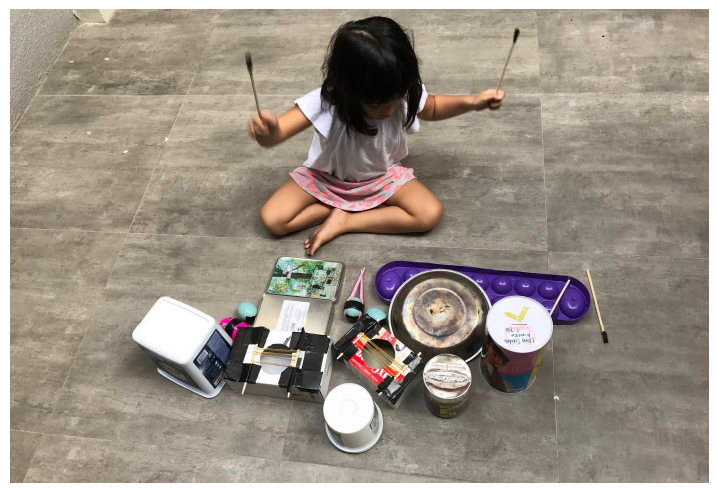

Fig. 5. Drum set using founded object and DIY instruments, 2019

\section{CONCLUSION}

It can be concluded that creativity is not about doing something better than others, but about imagining, exploring, thinking, creating something in a playful way. This game can be created through music and art activities such as making rhythmic music equipment. To be able to do activities that support the development of children's creativity, the environment has a very important role where we as parents can provide simple creative facilities from everyday life. Through the creative activities of music and art, automatically the children's motoric and cognitive performance will be better and they will become more critical of the surrounding environment. Things that can be obtained from the exploration of creativity through music and art activities are competent in artistic creativity and music; academic \& cognitive activities in thinking, processing, solving a problem, being able to see the possibilities that can occur; and the development of the psychosocial sector. As facilitators we should only give a little stimulus so that they have the desire to be more creative and evaluate them about what is best that can be developed in each individual child. The evaluation can be done by documenting its development from time to time, either in the form of photographs or journals. Allowing them to be open in their imagination and creativity, will make it easier for parents to see what areas their children are interested in later. They will also be more confident and responsible in making choices. 


\section{REFERENCES}

[1]. Utami Munandar, SC. (1981). “Aspek Psikologi dan Penerapannya, Analisis Pendidikan Departemen P\&K". Jakarta:Balai Pustaka Publisher.

[2]. Uce, Loeziana (2017) The Golden Age: Masa Efektif Merancang Kualitas Anak. Jurnal Pendidikan Anak UIN Ar-Raniry.

[3]. Kohl, MaryAnn F. (2015). "Fostering Creativity". Bright Ring Publisher.

[4]. Wien, Carol Anne. (2011) "Learnig to Document in Reggio-inspired Education". Early Childhood Research \& Practice Journal, Vol.3, No.2.

[5]. Biermeier, Mary Ann. (November 2015). "Inspired by Reggio Emilia: Emergent Curriculum in Relationship-Driven Learning Environments". Young Children Journal, Vol.70, No.5.

[6]. "Evidence That Children Become Less Creative Over Time (and How To Fix It)" https://www.ideatovalue.com/crea/nickskillicorn/2016/08/evidence-children-become-less-creativetime-fix/ August $5^{\text {th }} 2016$. Retrieved October $2^{\text {nd }} 2019$.

[7]. Farndon, John (2013). "Super Bright Baby. (50 things you really need to know)". London: Quercus. Publishing.

[8]. Flesh Connors, Abigail (2017). “101 Rhythm Instrument Activities for Young Children”. Gryphon House Publisher.

[9]. Hallam, Susan (November, 2018). “The Psychology of Music”. The Psychology of Everything.

[10]. Sarrazin, Natalie. (2012). "Music and the Child". Open Suny Textbook. Chapter 10: Children's Musical Play: Musicality and Creativity.

[11]. "Encyclopaedia Britannica, Rhtym Music" http://www.britannica.com/art/rhythm-music Retrieved 29 September 2019.

[12]. Widhianawati, Nana (August, 2011). "Pengaruh Pembelajaran Gerak dan Lagu Dalam meningkatkan Kecerdasan Musikal dan kecerdasan Kinestetik Anak usia Dini”. Journal academia.edu Edisi Khusus No.2.

[13]. Satiadarma, Monti P. and Zahra, Rswiyani P. (2004). "Cerdas dengan Musik". Niaga Swadaya Publisher.

[14]. Flesh Connors, Abigail (2015). "Shakes, Rattle and Roll: Rhythm Instruments and More for Active Learning". Gryphon House Publisher.

[15]. Mills, Hannah (2014). "The importance of creative arts in early childhood classrooms". Texas Child Care Quarterly Journal, Vol.38. No.1. 